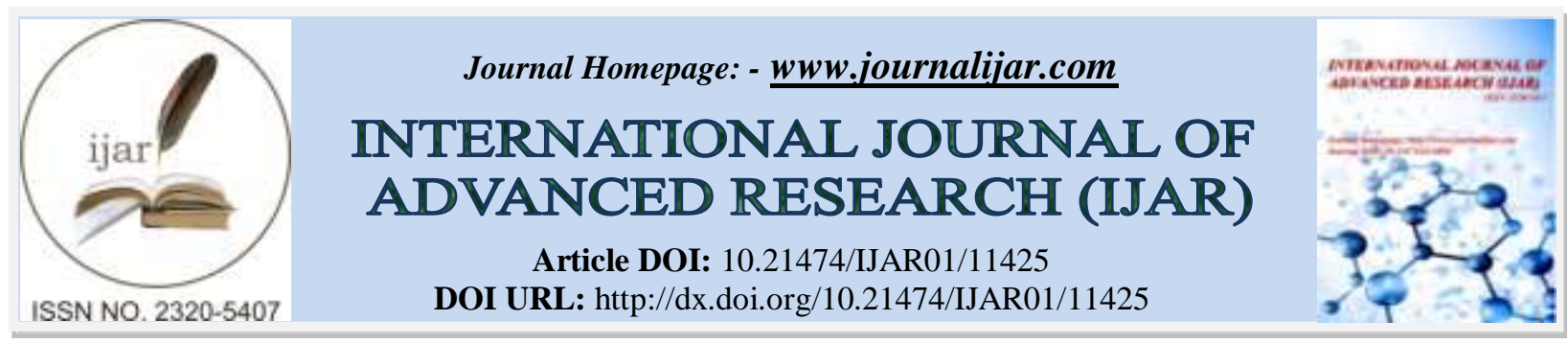

RESEARCH ARTICLE

\title{
ROLE OF Saraca asoca Linn. IN MENTAL HYGIENE - AN LITERARY REVIEW
}

\section{Vd. Madhura S. Dhatrak ${ }^{1}$ and Vd. Rupa S. Kadam ${ }^{2}$}

1. Final Year PG Student, Y.M.T. Ayurvedic Medical College \& Hospital, Kharghar, Navi Mumbai.

2. Associate Professor, Y.M.T. Ayurvedic Medical College \& Hospital, Kharghar, Navi Mumbai.

\section{Manuscript Info}

Manuscript History

Received: 28 May 2020

Final Accepted: 30 June 2020

Published: July 2020

Key words:-

Ashoka, Mental Hygiene, Mental

Health, Mana, Manas Vikara

\begin{abstract}
Mental health is an integral \& essential component of health. The WHO constitution states: "Health is a state of complete physical, mental \& social well-being \& not merely the absence of disease or infirmity." An important implication of this definition is that mental health is more than just the absence of mental disorders or disabilities. Mental health \& mental illness are two continuous concepts. People with optimal mental health can also have mental illness \& people who have no mental illness can also have poor mental health. Mental hygiene is "the art of preserving the mind against all incidents \& influences calculated to deteriorate its qualities, impair its energies, or derange its movements". By Sanskrit literature, Ashoka translates to grief less or no trouble, a word which denotes assurance $\&$ confidence. Being unparalleled in the management of gynaecological problems, Ashoka has been a woman's friend since ages. This sacred plant has a vast arena in aspects of mental hygiene of which yet has been unexplored to its potentials. Hereby we have tried to explore potentials of Stripriya Ashoka \& mental health by critical review.
\end{abstract}

Copy Right, IJAR, 2020,. All rights reserved.

\section{Introduction:-}

Even after ages of scientific studies \& development, the word "mental health" is a "taboo".

People with physical illness gain sympathy for their sufferings as a reflex action but it is difficult to gain the same level of attention or understanding for the people who struggle with their mental health. In our era of $21^{\text {st }}$ century, mental health workers face challenges in changing not only the mindset of the people but also get funding for the same. Narrowing down \& looking in the intricacies of mental health reports by many medical journals suggest that "women are nearly twice as likely as men to suffer from mental illness." The pressure of gender roles set by the society, the competition at the workplace \& many other gender inequalities leads to gender disparities creating depressive disorders. These problems have correlation between gender inequality \& gender disparities in mental health.

The scenario of education \& working population has changed dramatically due to rapid development in the country \& competitive approach to be best at every single opportunity grabbed. This pattern has, in turn, caused serious implications to human interpersonal relationships \& its dynamics which have been rapidly changing, at times projected into a scenario of violence.

Corresponding Author:- Dr.Madhura.S.Dhatrak

Address:- PG scholar, Department of Dravyaguna, Yerala Medical Trust's Ayurvedic Medical College 
These implications have taken a lead in form of various mental disorders like anxiety, stress, depression, psychosis \& bipolar disorders in turn leading to serious medical conditions like endocrinological disorders, hypertension, diabetes, cardiac diseases, neurological problems, etc.

The WHO constitution states: "Health is a state of complete physical, mental \& social well-being \& not merely the absence of disease or infirmity." Mental health is an integral \& essential component of health.

An important implication of this definition is that mental health is more than just the absence of mental disorders or disabilities.

It is mental well-being in which an individual realizes his/ her abilities, can cope with normal stresses of life, can work productively \& can make a contribution to his/ her society \& country in a broader arena.

Hence, mental health is a foundation for well-being of an individual \& the effective functioning of the community. [1]

Mental health \& mental illness are two continuous concepts.

Mental health is a positive concept related to the social \& emotional wellbeing of individuals $\&$ communities.

Mental illness refers collectively to all diagnosable mental disorder's conditions characterized by alteration in thinking, mood \& behaviour associated with distress or impaired functioning.

Psychological Factors contributing to mental illness are severe psychological trauma suffered as a child, such as emotional, physical, or sexual abuse, an important early loss, such as the loss of a parent, neglect, poor ability to relate to others.

Environmental factors contributing to mental illness in a person susceptible are certain stressors that can be a triggering factor such as death or divorce, dysfunctional family life, feelings of inadequacy, low self-esteem, anxiety, anger or loneliness, changing jobs or institutions, social or cultural expectations, substance abuse by a person or his/ her family or closed ones.

Mental hygiene is "the art of preserving the mind against all incidents \& influences calculated to deteriorate its qualities, impair its energies, or derange its movements". It refers to all the activities \& techniques which encourage as well as maintain mental health. ${ }^{[2]}$

The critical review of few medical journals suggested that the proportionate contribution of mental disorders to the total disease burden has almost doubles since 1990, which amounts to 19.73 crore population of country reeling under one or other mental disorder. Initially, a handful of people in society were vocal about mental health as a major concern irrespective of gender but seems to have failed to think about mental hygiene. Description of this concept in Ayurveda was already done by ancient scholars which we have tried to explore in various angles.

\section{Material \& Methodology:-}

Critical review of ayurvedic compendia especially charak samhita alongwith ashtang hriday \& bharprakash nighantu were mainly referred for this study. Supportive texts \& references from conventional medicine, jouranls \& internet source were also studied to comprehend the ancient literature.

In process of this review it was noted that there is some ambiguity related to concept of manas vikara \& its probable modes of treatment. Hence this study was done to clarify the correlation of colour psychology, aroma therapy in relation to mana $\&$ its vikara alongwith aspects of cultivation.

\section{Review of literature:-}

Concept of mana \& mental health:

The concept of mana has been given immense importance in ayurveda. The high prevalence of manas vikara in today's era is a major subject of concern which can be correlated to mental disorders in conventional medicine. 
Mana means the one which does manana, bodhana \& through which knowledge is perceived. ${ }^{[3]}$

The gunas of mana are anutva \& ekatva. ${ }^{[4]}$

Acharya charak has defined life (ayu) is the combined state of sharira ( body), indiryas

(senses ) \& sattva ( psyche / mind ). The teaming of all three has one responsible common factor which is Mana.$^{[5]}$

A human body is said to be healthy when there is balance \& harmony among doshas \& dhatus alongwith normal digestion, uninterrupted excretion of waste products in addition to tranquility \& clarity of soul, mind $\&$ senses. ${ }^{[6]}$

According to Ayurveda hriday ( heart ) \& mastishka ( brain ) are well recognized as two separate vital organs as well as mentioned to be adhishthana of mana. Uppermost chief organ of all sense organs is brain whereas heart is considered to be seat of buddhi \& sadhak pitta regulates its proper functioning. ${ }^{[7]}$

The relation of shira ( head) with indriya ( cognitive organs) \& pranavaha strotas ( vital centres \& their connected path ); the relation of hriday ( heart ) with the mana ( psyche ), buddhi ( intellect ), chetana ( consciousness ) \& mahabhutas ( proto elements ) has been well mentioned by Acharya charak in charak samhita.

The buddhi vyapara ( accomplishment of intellect) occurs after mano vyapara ( psychic action ) for attaining the deterministic knowledge. Hereby mana \& buddhi are reciprocally related to each other i.e.gyan utpatti karma ( gaining the knowledge ).

The sadhak pitta is essentially responsible for higher mental faculties \& emotional states.it is also responsible for various psychological functions such as shourya ( courage ), bhaya ( fear ),krodha ( anger ), harsha, etc. ${ }^{[8]}$

The emotions are shown to be deeply related to \& dependant on heart. The pathogenesis of mental diseases depicts the association of heart with them.

\section{Pathophysiology:}

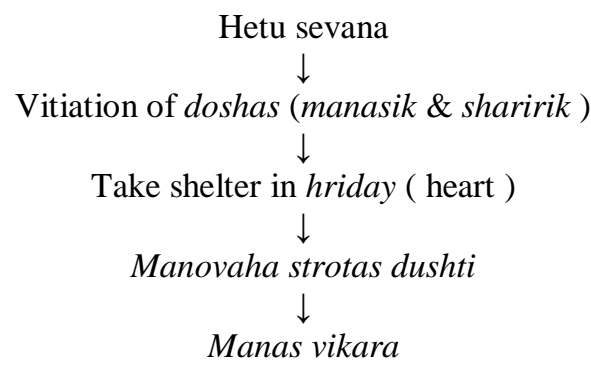

The similar concepts regarding mana have also been told by Acharya sushruta \& Acharya vaghbhata.

\section{Reproductive \& mental health in women:}

The perpetuity of an individual's life can be divided into several life stages with certain features \& characteristic of each stage. Developmental psychology recognizes themes characteristic to each stage that change with age. Capturing the concepts of life stages is useful in understanding the status \& position of other people.

Biologically, life stages of a typical woman are divided into infancy, puberty (adolescence), sexual maturation (reproductive age), climacteric period, \& post-climacteric (elderly) years. Some stages include fluctuations in the hormonal milieu as well as the life events specific to women, namely pregnancy \& delivery

Hormones interact with each other \& control ovulatory cycles within the short-spanned temporal axis of menstrual cycles, \& it is not unusual for such hormonal changes to induce certain signs \& symptoms associated with menstruation.

Graphical representation of Life stage related mental health issues and diseases unique to women 


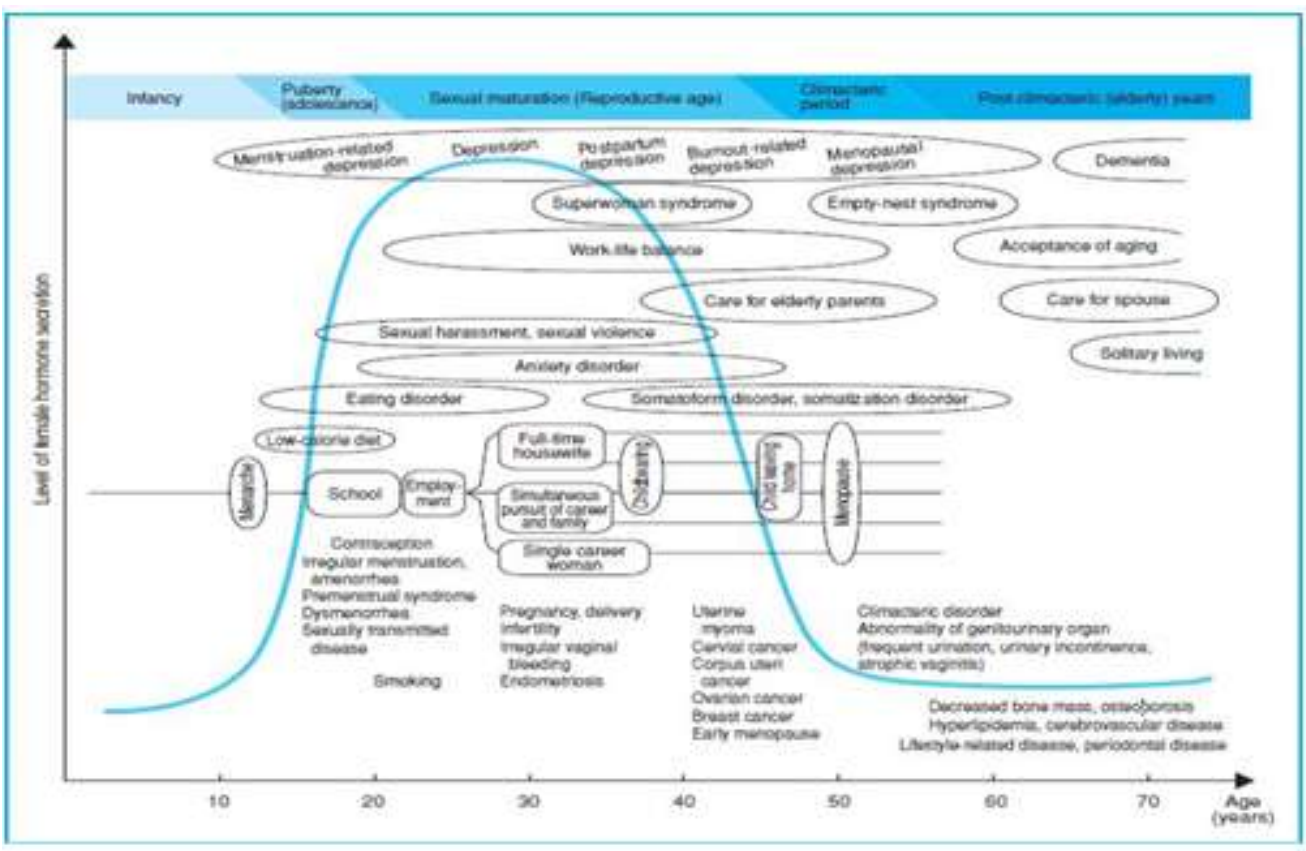

On the other hand, to consider women's health issues from a wide point of view beyond biomedical problems \& psycho-social \& social aspects, it is necessary to obtain insight into the physical characteristics of women in each life stage $\&$ their roles in the socio-cultural context in order to understand their mental \& social background.

Different health issues may arise from the livelihood of each stage, some manifest as physical symptoms. Because health status in one stage influences the next stage, having knowledge of the framework of life stages can bring deeper empathic understanding \& lead to the discovery of potential problems \&/or solutions.

Hence, reproductive health factors \& gynecological symptoms may actually be somatic equivalents of common mental disorders in Asian women. ${ }^{[9]}$

The critical review of few medical journals suggested that the proportionate contribution of mental disorders to the total disease burden has almost doubles since 1990, which amounts to 19.73 crore population of country reeling under one or other mental disorder. ${ }^{[10]}$ Hereby, statistical data by WHO states that women are more affected by mental health. ${ }^{[1]]}$

The scenario may seem to be troublesome on global platform whereas the solution seems simple as suggested by Ayurveda acharyas i.e. the stripriya ashoka

\section{Literature Review:-}

Ashoka:

Latin name - Saraca asoca Linn.

Family - Caesalpinionaceae

According to Sanskrit literature,

अशोक: = नास्ति शोको यस्मात् । ${ }^{[12]}$

$A-$ denotes absence $;$ SHOKA - denotes grief or sorrow Absence of grief or sorrow $=$ Ashoka

The Ashoka tree is considered sacred throughout the indian subcontinent. It is highly valued for its handsome appearance due to its abundance $\&$ colour pallette of flowers alongwith its mild aroma. ${ }^{[13]}$

This tree was abundantly found in many temples, gardens \& royal palaces. 


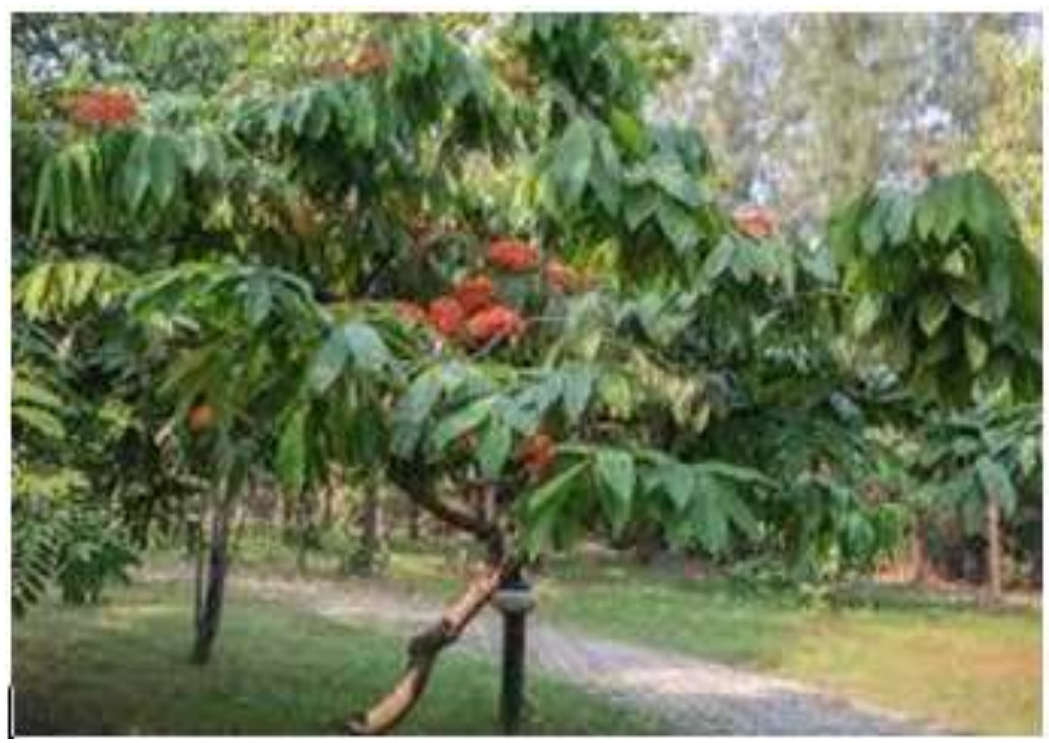

Mythological history of ashoka. ${ }^{[14]}$ :

1. Queen Maya gave birth to lord Gautam Buddha under ashoka trees in beautiful garden of lumbini park, Nepal, where she stepped down from her palanqum to have walk while she was returning back to her own home for birth. She reached for the ashoka branch to take rest as she was elated by the park.

2. Yakshis underashoka tree were considered to be decorative element of hindu / indian sculpture \& was integrated into the indian temple architecture as salabanjika

3. Goddess sita was captivated in ashoka vatika in lanka by lord ravana in lanka as mentioned in indian epic Ramayana as well as in Vishnu purana.

\section{Geographical Distribution:}

Geographically it is majorly distributed in indian subcontinent ( central area of deccan plateau, as well as middle section of the western ghats in the western coastal zone ) alongwith adjacent areas like Nepal, Sri lanka, central \& eastern Himalayas, northern plains of india \& west coast of the subcontinent near Mumbai. ${ }^{[15]}$

Various Synonyms of Ashoka \& Its Etymological Derivation ${ }^{[16]}$ :

According to the Sanskrit literature, many synonyms have been assigned which relates to characteristic features \& various activities of ashoka.

\section{तत्पर्यायः ।}

१ शोकनाशः २ विशोकः $३$ वर्जुलद्रुमः ४ वर्जलः $\varphi$ मधुपुष्पः \& अपशोकः $७$ कड्केल्लिः ८ केलिकः $९$ रक्तपल्लवः

१० चित्रः ११ विचित्रः १२ कर्णपूरः १३ सुभगः १४ दोहली १९ तामपल्लवः १६ रोगितरुः १७ हेमपुष्पः १८ रामा १९ वामाङ्ध्रिघातनः २० पिण्डीपुष्पः २१ नटः २२ पल्लवद्रुः ।

\section{1) अशोक, विशोक, शोकनाश, अपशोक ( न शोकोडस्मत् शोकनाशन इत्यर्थः । )}

It does not cause sorrow or reduces grief.

\section{2) तामपल्लव ( तामपर्णाः पल्लवा अस्य । )}

Tender leaves of this plant are copper red in colour.

\section{3) मधुपुष्प ( मघौ वसन्ते पुष्पयति । )}

Flowers of the plant blossom in spring season.

\section{4) कन्केलि ( कं सुखं केलति जनयति आल्हादकरः I)}

It generates pleasure. 


\section{5) रक्तपल्लव (रक्तवर्णाः पल्लवाः अस्य । )}

Tender leaves of this plant is somewhat red in colour.

6) चित्र

This plant is very wonderful $\&$ bright. It has an extra ordinary appearance.

\section{7) कर्णपूरक}

It is used as an ornament worn around the ear.

\section{8) सुभग}

It has a beautiful look \& its sight is considered to be very auspicious.

\section{9) स्मराधिवास}

It is considered to be abode of remembrance \& love.

10) दोषहारि It alleviates the doshas that causes the health problems in the body.

\section{1) गन्धपुष्प ( सुगन्धिपुश्पत्वात् I )}

Flowers of this tree are aromatic in nature.

\section{2) हेम्पुष्प ( स्वर्णाभानि पुष्पाणस्य । )}

Flowers of this tree has golden lusture.

\section{3) पिण्डिपुष्प ( पिण्डाकाटः सघनाःपुश्पगुच्छा अस्य )}

The tree bears flowers in dense clusters.

\section{4) स्त्रिप्रियः ( स्त्रीणां प्रियः स्त्रीरोगेशु हितत्वात् I )}

The tree is liked by women \& is also useful in treating gynaecological disorders.

Medicinal attributes of ashoka ${ }^{[17]}$ :

अशोकः शीतलस्तिक्तो ग्राही वर्ण्य: कषायकः ।

दोषापचीतृषादाहकृमिशोषविषास्रजित् ॥

\section{(भा.प्र.)}

Rasa - kashaya, tikta

Virya - sheeta

Vipaka - katu

Guna-laghu, ruksha

According to colour psychology, colours affect human behavior which have psychological properties relating to body, mind, emotions \& essential balance among all of three.

Every single colour have their properties which exert some effect but combination of colours alongwith aroma \& music exert even more better effect on humans. ${ }^{[18]}$

\section{पित्तस्य सर्पिषः पानं स्वादुशीतैर्विरेचनम् ।}


स्वादुतिक्तकषायाणि भोजनान्यौषधानि च ।।४॥

सुघन्धिशीतहुद्यानां गन्धानामुपसेवनम् ।

कण्ठगुणानां हाराणां मणीनामुरसा ध्रुतिः ॥५॥

कर्पूर चन्दनोशीररैनुलेप: क्षणे क्षणे ।

प्रदोषश्चन्द्रमा: सौधं हारि गीतं हिमोऽनिलः ॥६॥

अयन्त्रणसुखं मित्रं पुत्र: सन्दिग्धमुग्धवाक् ।

छन्दानुवर्तिनो दारा: प्रिया: शीलविभूषिता: ॥७॥

शीताम्बुधारागर्भाणि गृहाण्युद्यानदीर्घिका:।

सुतीर्थविपुलस्वच्छसलिलाशयसैकते ॥८॥

साम्भोजजलतीरान्ते कायमाने द्रुमाकुले ।

सौभ्या भावा: पय: सर्पिविरेकश्च विशेषतः ॥९॥

(अष्टांग हुदय, सू.९३ / ४-९)

Flowers of ashoka have rich colour pallete that grabs attention. Predominantly color yellow followed by colour orange \& eventually colour red on full maturation, alongwith colour green of leaves of the tree.

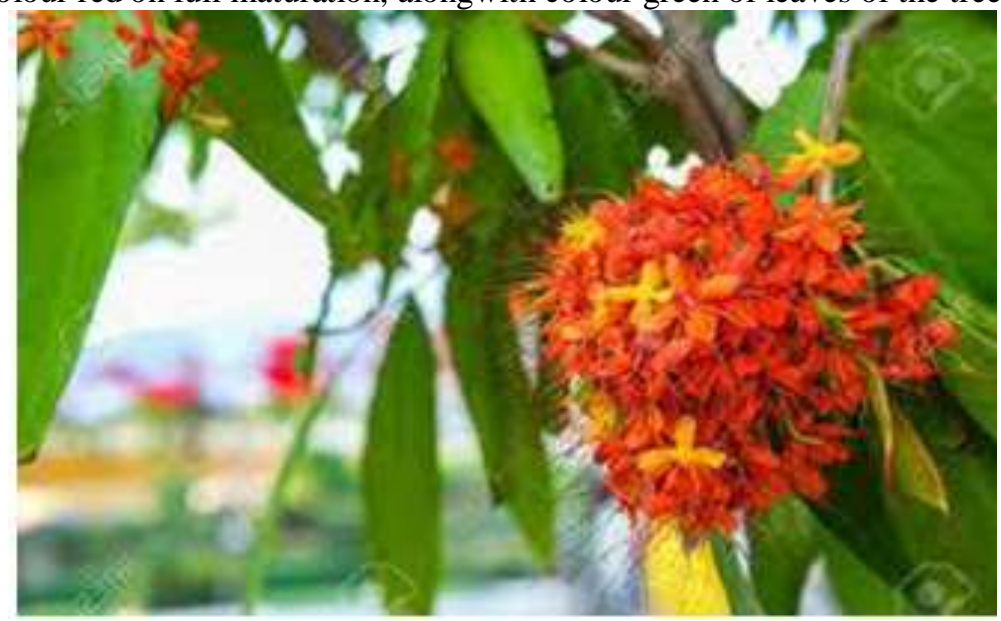

Hence, also it was suggested to be cultivated in gardens \& in vicinity of houses. ${ }^{[19]}$

अथोद्याने प्रवक्ष्यामि प्रशस्तान्यादपाद्विज ।

अरिष्टा-शोक-पुन्नाग-शिरिषा-म-प्रियडगवव ॥ १० ॥

पनसा-शोकदचली-जम्बू-लकुच-दाडिमाः ।

माङगल्याः पूर्वमारामे रोपणीया गृहेषु वा ॥ ११ ॥

All these colours have their own characteristic features \& have different meanings to various demographics, age groups, cultures, nationalities.

Characteristic Features of Colours ${ }^{[20]}$ :

Red:

Being the longest wavelength, red is a powerful colour.

Although not technically the most visible, it has the property of appearing to be nearer than it is \& therefore it grabs our attention first. Hence its effectiveness in traffic lights the world over. Its effect is physical; it stimulates us \& raises the pulse rate, giving the impression that time is passing faster than it is. 
It relates to the masculine principle \& can activate the "fight or flight" instinct. Red is strong, \& very basic. Pure red is the simplest colour, with no subtlety. It is stimulating \& lively, very friendly. At the same time, it can be perceived as demanding $\&$ aggressive.

\section{Yellow:}

The yellow wavelength is relatively long \& essentially stimulating.

In this case the stimulus is emotional, therefore yellow is the strongest colour, psychologically.

The right yellow will lift our spirits \& our self-esteem; it is the colour of confidence \& optimism. Too much of it, or the wrong tone in relation to the other tones in a colour scheme, can cause self-esteem to plummet, giving rise to fear \& anxiety.

\section{Orange:}

Since it is a combination of red \& yellow, orange is stimulating \& reaction to it is a combination of the physical \& the emotional.

It focuses our minds on issues of physical comfort - food, warmth, shelter etc. - \& sensuality. It is a 'fun' colour.

\section{Green:}

Green strikes the eye in such a way as to require no adjustment whatever $\&$ is, therefore, restful. Being in the center of the spectrum, it is the colour of balance - a more important concept than many people realise.

When the world about us contains plenty of green, this indicates the presence of water, \& little danger of famine, so we are reassured by green, on a primitive level.

\section{Tradiotional history of ashoka ${ }^{[21]}$ :}

Today's era has witnessed massive deforestation \& degradation of the environment. The disastrous consequences of this in form of global warming \& unavailability of the precious medicinal herbs have been cited many a times in many research studies but go ignored until a major supply is demanded for its use.

Historically the protection of nature \& wildlife was an ardent article of faith, reflected in the daily lives of people, enriched in myths, folklore, religion, arts \& culture.

Such traditional cultural attitudes though based on religious faith have made significant contribution in protection \& propagation of various species of trees \& plants in india. Environmental conservation is no new concept for Indians. It was substantially was ingrained in the thought processes of Indians as evident from teachings of vedas. Provision of such profound variety of cultural practices \& ecologically sound relationship with nature is not described in any other culture.

Mythological stories have been useful in cultivating certain plants at an extent that socio-culturally valued species \& sacred ones found their places in homes, gardens \& courtyards because of their medicinal/ aesthetic/ natural qualities as well as their proximity to particular deity.

In India, married hindu women eat the flower buds of saraca asoca on the 'Ashok shashthi day' to guard their children against grief \& sorrow by invoking deities.

The individuals suffering from mental disorder are advised to take bath under the shade of ashoka tree. They are also advised to put powdered seeds inside the beetle leaf (pan) \& eat it empty stomach.

For mental peace, the natives prepare special herbal maala (necklace) using pieces of roots of sita ashoka \& give it to patients.

It is widely used medicinal herb in ayurveda to cure various gyanaecological disorders as well as it is mentioned to possess varnya properties. 
References of plantation of this beautiful tree has been cited in ancient science named 'vriksha ayurveda' . [19]

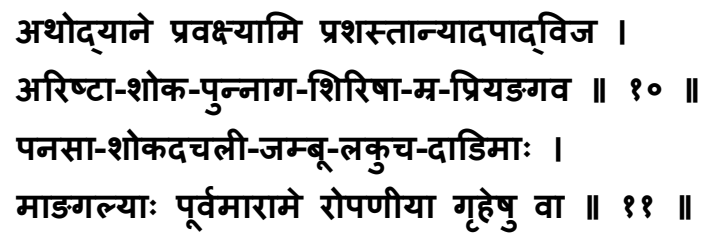

Also the verse from brihat samhita states beautiful description regarding plantation of specific trees in garden or in garden adjoining one's house. Ashoka is one of them, as it is eminently conducive to the welfare of the house i.e. mangalamaya.

\section{Discussion:-}

GOD is a magnificient creator. He created universe, five elemental forces of Nature which governs the entire universe and many more things beyond our imagination. Amidst these various innovations, is the prodigy of procreation.

Procreation in another words, is the desire to reproduce own species through sexual act.

The fundamentals in nature, namely Prakriti \& Purush acts as driving force, which replicates the Female \& Male gender respectively in all living creatures. According to Ayurveda, the factors that hold prime importance in the process of conception is not just healthy sperm \& ovum but also an equal \&/or more emphasis is given on metabolic function, hormonal balance \& mental/emotional health which has an inter-connections among all these factors for contribution in making of healthy society in all aspects.

\section{Conclusion:-}

By Sanskrit literature, Ashoka translates to grief less or no trouble, a word which denotes assurance \& confidence. Ashoka has been a woman's friend since ages. This sacred plant has a vast arena in aspects of mental hygiene of which has been now explored to its potentials by critical literature review.

The IUCN has listed this tree in category of vulnerable species which is now getting threatened due to mass deforestation as well as improper identification of species. Hereby we must try to make use of best preventive as well as curative potentials of Stripriya Ashoka in vast arena by cultivating it \& conserving it in various forms at best.

\section{Further Scope:}

Cultivation, propagation \& conservation of Saraca asoca Linn. i.e. ashoka trees on large scale in premises of schools, colleges, gardens \& in vicinity of house or housing complexes alongwith its proper identification training $\&$ awareness of its multi-directional benefits to people in daily life.

\section{References:-}

1. World Health Organization. ( 2005). Promoting mental health : concepts, emerging evidence, practice : a report of the World Health Organization, Department of Mental Health and Substance Abuse in collaboration with the Victorian Health Promotion Foundation and the University of Melbourne. World Health Organization

2. https://en.wikipedia.org/wiki/Mental_health

3. Raja Radha Kantadeva Shabdakalpadruma by Chauwkambha Samskrita Series Varanasi 3rd edition 1967.

4. Charaka Samhita : With Ayurveda Dipika Commentary by Chakrapani Datta Chaukhamba Orientalia Varanasi (1989).Ch.sha.1/19

5. Charaka Samhita : With Ayurveda Dipika Commentary by Chakrapani Datta Chaukhamba Orientalia Varanasi (1989).Ch.su.1/42

6. Astanga Hrdaya Samhita: By Acharya Vagbhata with the commentaries: Sarvangasundara of Arundatta and Ayurveda Rasayana of Hemadri.Pub.by Chaukhamba Surabharati Prakasana -Varanasi A.Hr.su.1/2

7. Kashinath Shastry, Vaidya Yadavatrikamaji Achar, Agnivesha Charakasamhita Chakrapanidattavirachita Ayurvedadipikavyakhyanahindi Sutrasthana 30th chapter, 4th verse 4 th edition 1994. Chowkambha Sanskrit samsthana, Varanasi. 
8. Agnivesha, sutra sthan in Sharma RK and Dash B.Charaksamhita (with English translation and critical exposition based on Chakrapani dutt's Ayurveda dipika) vol I, Chowkhambha Sanskrita Series, Varanasi, sixth Edition;2009. p.335

9. understanding the life stages of women [Internet]. Med.or.jp. 2020

10. https://www.med.or.jp/english/journal/pdf/2010_05/273_278.pdf ]

11. [En ligne]. Sagar R, Dandona R, Gururaj G, Dhaliwal R, Singh A, Ferrari A et al. The burden of mental disorders across the states of India: the Global Burden of Disease Study 1990-2017; 2020.

12. Who.int [En ligne]. WHO | Gender and women's mental health; 2020 [cité le 23 July 2020]. Disponible: https://www.who.int/mental_health/prevention/genderwomen/en/

13. Raja Radha Kantadeva Shabdakalpadruma by Chauwkambha Samskrita Series Varanasi 3rd edition 1967.

14. Isolation and Characterization of a Steroid Resembling Bioactive Compound from Saraca Indica Bark. International Journal of Pharmacy and Natural Medicines [En ligne]. 2015 [ http://ijpnm ]

15. https://en.wikipedia.org/wiki/Saraca_asoca\#: :text=It $\% 20$ is $\% 20$ believed $\% 20$ Shakyamuni $\% 20$ Buddha,with $\% 20$ the $\% 20$ yakshi $\% 20$ mythological $\% 20$ beings.\&text=Yakshis $\% 20$ under $\% 20$ the $\% 20$ ashoka $\% 20$ tree, many $\% 20$ anci ent $\% 20$ Buddhist\%20archaeological\%20sites.

16. Isolation and Characterization of a Steroid Resembling Bioactive Compound from Saraca Indica Bark. International Journal of Pharmacy and Natural Medicines [En ligne]. 2015 [ http://ijpnm ]

17. Raja Radha Kantadeva Shabdakalpadruma by Chauwkambha Samskrita Series Varanasi 3rd edition 1967.

18. Prof.k.c.chunekar,dr.g.s.pandey-bhavprakash nighantu-pushpavarga-reprint 2015-chaukhambha bharati academy, Varanasi, page 487

19. Vaidya Sachin Kulkarni, Vaidya Yash Shri Joshi, Vaidya D.P.Gadgil, Ashtang Hriday - Sutrasthan - 4 Th Edition 2017, manikarnika publication, page 229

20. Surapalas Vrikshayurveda: ancient treatise on plant life. Editor Dr Shrikrishana jugnu, Chaukhamba Sanskrit Series office, Varanasi. 2004

21. http://www.colour-affects.co.uk/psychological-properties-of-colours

22. Isolation and Characterization of a Steroid Resembling Bioactive Compound from Saraca Indica Bark. International Journal of Pharmacy and Natural Medicines [En ligne]. 2015 [ http://ijpnm ]. 